\title{
ガス絶縁変圧器ターン間絶縁モデルの 急峻波領域における絶縁特性
}

$\begin{array}{lllll}\text { 正員 } & \text { 井上 } & \text { 保 } & \text { (東 } & \text { 芝) } \\ \text { 正員 } & \text { 寺西 } & \text { 常治 } & \text { (東 } & \text { 芝) } \\ \text { 正員 } & \text { 谷口 } & \text { 安彦 } & \text { (東 } & \text { 芝) } \\ \text { 正員 } & \text { 戸田 } & \text { 克敏 } & \text { (東 } & \text { 芝) } \\ \text { 正員 矢成 } & \text { 敏行 } & \text { (東 } & \text { 芝) }\end{array}$

Dielectric Characteristics of Turn- to-Turn Insulation Models of Gas-Insulated

Transformer under Very Fast Transient Voltages

Tamotsu Inoue,Member Tsuneharu Teranishi,Member Yasuhiko Taniguchi,Member

Katsutoshi Toda,Member Toshiyuki Yanari,Member

(Toshiba Corpration)

This paper deals with the partial discharge inception voltage (PDIV) and breakdown voltage (BDV) characteristics of turn-to-turn insulation models for $\mathrm{SF}_{6}$ gas-insulated transformers under steep front short pulse voltages, of which waveforms are $35 / 65$ ns and 50/370 ns. It was found out that PDIV under nano-second pulses were $1.05 \sim 1.15$ times higher than those under standard impulse voltages and BDV under nano-second pulses were about 1.4 times higher than those under standard impulse voltages. The ratio of impulse PDIV to ac PDIV is $1.40 \sim 1.48$ for standard impulse voltages and $1.32 \sim 1.37$ for switching impulses.

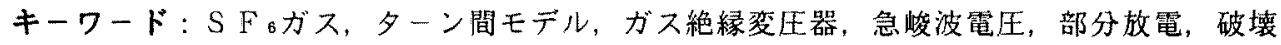

\section{1、まえがき}

SF日がスを絶縁媒体に用いたガス絶縁変圧器は、变電所 防災の観点からそのニーズとともに適用が拡大されている。 ガス絶縁変圧器は巻線の絶縁方式、冷却方式の違いから様 々な方式に分類され、それぞれ275kVクラスの変王器が製作 されている《1。巻線の絶縁、冷却ともSF。ガスで行うが ス冷却式ガス絶縁変压器は低電压小容量クラスが従来より 実用化されていたか、近年においては275kV、300MVAまでの 変压器が完成している(2)。ガス冷却式ガス絶縁方式の巻線 には絶縁被覆平角線が使用さ机ているか、、そ扎らの絶縁特 性についてはこ机までにも報告険討されている。例えば最 近では、長期信頼性を㛟討した交流V-特性及びィンパルス 電压の V-n 特性についての報告がある(ろ)。

ガス絶縁变压器はその絶縁構成から、ガス絶縁開閉装置 (GIS) と直結して変電所スペースを有効に活用できること が利点の1つになっている。しかしこの場合、GISの操作に よって断路器サージなどの急峻波サージが発生することは 良く知られていることであり(4)、そのサージ電圧がそのま ま変圧器に侵入し、変生器巻線線路端近傍のターン間、七

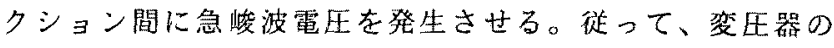
巻線絶縁強度、特に絶縁信頼性を考える場合、雷インパル ス電圧のみならず急峻波電压に対する䋓縁強度の把握も重
要となる。急峻波サージ電圧に対する絶縁強度の調查は、 GIS 関連で不平等電極を使用した研究が多くなされてい る(b)。変正器絶縁に対しては、油浸絶縁紙での例が報告さ れている(日)が、ガス絶縁変在器における絶緑強度につけて の検討はこれまであまりないようである。

ここでは、ガス冾却式ガス絶縁変圧器のターン間絶影を 模擬したモデルを使用して急峻波電圧を始めとした各種の 電止に対する部分故電開始電圧および破壊電壬の調查結果 さらに、比較のため実施した被覆した球電極を用いて謂目 した微小ガスギャップの部分故電開始電压特性について述 ベる。

\section{2. 試馀方法}

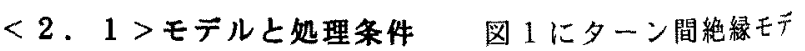
ル形状を示す。モテルは内鉄型変王器のターン間を模强し たもので 2 種類のモデルで試騃した。モデル(a)は部分放䉓 開始電圧を調查するために使用したもので平角銅線（2.2X

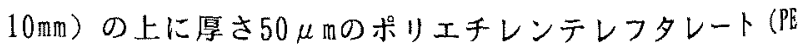
T)フィルム所定の厚さに巻いた絶縁被覆平角線を5本 (または 3 本)を組み合わせて変圧器のターン間を模掓 ている。そして、その絶縁被覆平角線を挟むように䋓緑久 ペーサが 2 力所取り付けてある。このモテルでは、インハ ルス部分放電を感度良く測定するため、接地側の銅線を使 
用して電流法のバランス回路を構成した。モテル(a)では口 出し部分への登面破壊による絶縁破壊を生じるため部分故 電開始電瓜のみを求め、モテル(b)で破壊電圧を求めた。 モデル(b)は部分放電開始電理とともに破壊電压を調查す るものでモデル(a)上同じ絶縁被覆平角銅線 2 本を抱き合わ せてターン間を構成している。

モデはは加熱乾燥をしたのち試験用タンク内にセットし た。そして、10Pa以下の玨力まて真空引きし、その後S F。 ガスを0.5MPaまで封入して試䍉に用いた。

モデルの試駼㮯数は1試馱条件ら〜10個である。

图 2 に被覆球ギャップモデルを示す。球電極は直径 $40 \mathrm{~mm}$ のボールベアリングでその表面荒さは $0.15 \mu$ 几である。その 電極表面に厚さ $25 \mu$ m いる。ギャップ長は30倍の顕微鏡を使用して零点を定め、 マイクロメーターを使用して調節した。試験時のギャッブ 長は0.5mm一定とした。試娩回数は、1条件10回である。

$<2 ， 2>$ 電王印加方法 ターン間モデルの試験は、2 程類の急唆波電压、雷インパルス電压 (L.Imp) ( $\pm 1.2 / 50 \mu \mathrm{s})$ 開閉インパルス舟圧 (S. Imp) ( $\pm 250 / 2500 \mu \mathrm{s})$ およひ交流 電纴 $(\mathrm{ac})(50 \mathrm{~Hz})$ を印加しておこなった。被覆球電極モテル
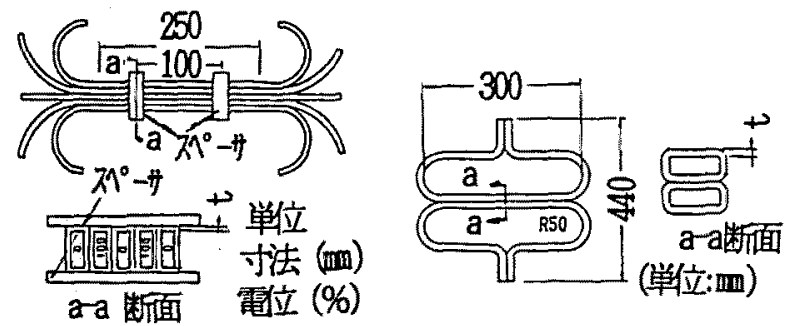

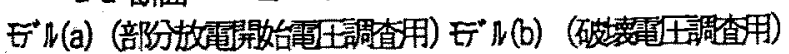

図 1 ターン間絶縁モデル形状

Fig. 1. Structure of turn-to-turn insulation models

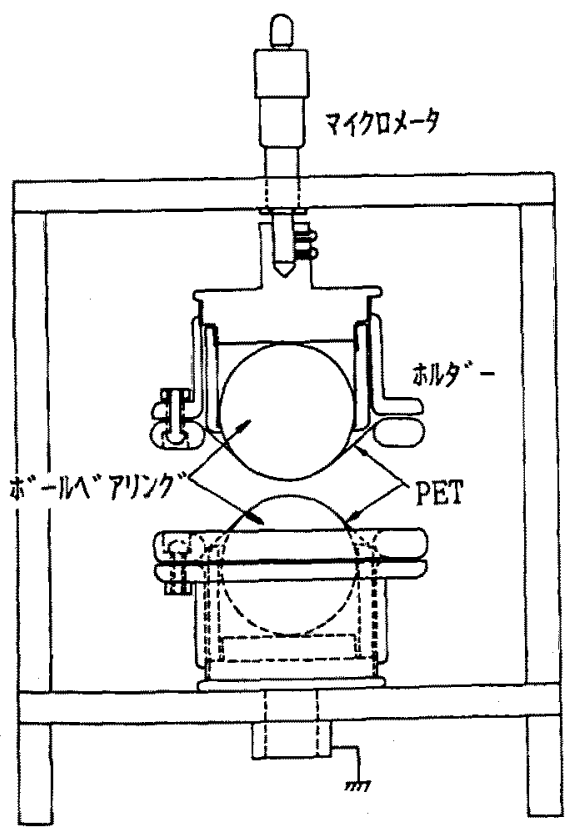

图2 被得球電極

Fig. 2. Structure of covered sphere electrode

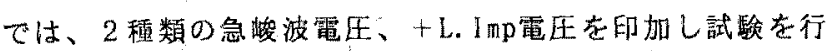
った。ターン間モデル(a)で 5 本組(または 3 本)の各銅 線の交互に電匡を加え、他の銅線を接地した。ターン間モ テル(b)では片方の銅線に電王を加え、他方は接地とした。 同様に、被覆球ギャップモデルでは片方の電極に電压を加 え、他方は接地とした。

（1）急峻波電压の発生方法急峻波電圧の発生にはブ ルームライン回路を使用したパルス発生装置を用いた。図 3 にその試験回路を示す。ブルームライン回路の構造は二 重同心状の同朝円筒線路上なっており、中心筒冠体上中 間円简導体はスパイラル構造として、全長 $1 \mathrm{~m}$ の装置で所 定のパルス輻を得るようにしている〈7〉。発生電圧は $1 \mathrm{CH} z$ 急

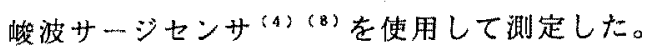

試験に使用した電压波形を図 4 に示す。電死波形は、立与

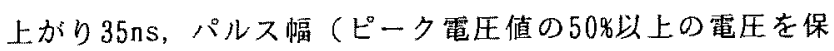
つ時間）65nsおよび立ち上がり50ns，パルス幅370nsである。 今後これらの電压ををれぞれ35/65ns, 50/370ns之記す。

(2) 急峻波電压の試験方法電压印加は予想される部 分放電開始電压(PDIV)の約50\%より1〜2kVステップで電压を 上昇させPDIVを求め、それ以上の電压では2 5kVステップ で上昇させるステップアップ法によった。そして、PDIVと 破壊電压(BDV)を求めた。電圧印加回数は各ステップ 1 回で ある。PDIVは銅線の接地倒心貫通型の高周波CT (立ち上が り応答時間10ns）を取り付けた電流法のバランス法 ${ }^{(9)}$ とイ メージインテンシファイア (1. I, 光增倍率 $10^{8}$ 倍) を使用 して部分放電に伴う発光を撮影する方法を併用して求めた。 L. Impおよび50/370ns電压を印跬し、PDIVを测定した結果、 電流法による部分放電の検出と発光が観測される電压は一 致していた。しかし、パルス幅の短い35/65nsの電圧では、 バランス法を用いても完全に充電電流をキャンセルできず、 電流法のみではPDIVを求めることが困難な場合があった。 その場合は、発光を観察する方法にてPDIVを求めた。電流 法のインパルス部分放電测定で、检出された電流パルスを 時間皘分して部分放電電荷を求め大結果、200pC以上の部分 故電の検出が可能てあった。

(3) 雷インパルスおよび開閉インパルス試験方法電压 は、インパルス発生器を用いて発生させた。電压は急股波 電压と同じステップアップ法で印加し、PDIV及びBDVを求め た。電圧印加回数は各ステップ 1 回である。

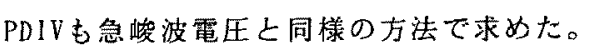

(4) 交流部分放電試跧方法電王は予想されるPDIV0

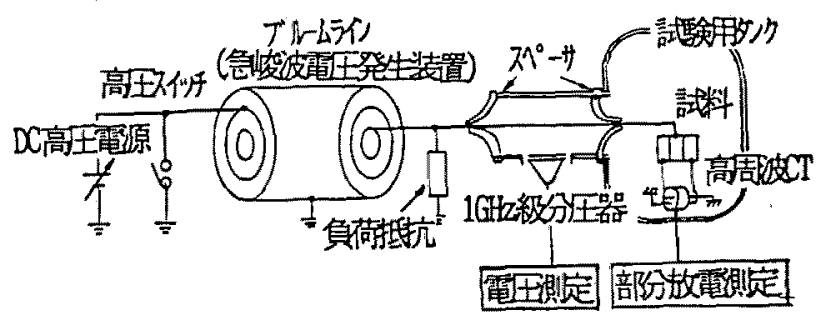

図3 急峻波電圧試倹回路

Fig. 3. Test arail for steep front short duration pulse vol tage 


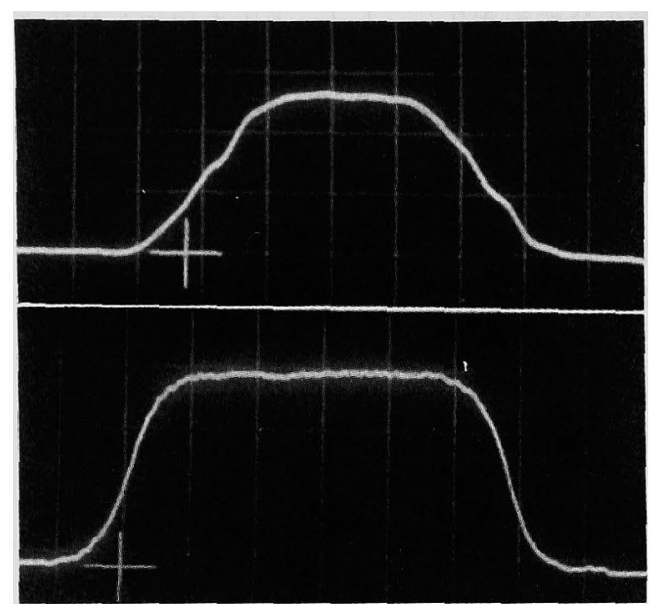

$15.5 \mathrm{~ns} / \mathrm{div}$

図 4 急峻波電圧波形

Fig. 4. Voltage waveforms of steep front short duration pulse voltage

䄪 $50 \%$ より $1 \mathrm{kV}$ rmsステップで各 1 分間保持しながら上昇させ る1分間ステップアップ法で印加した。部分放電はERA法に よって測定した。部分放電検出感度は $0.7 \mathrm{pCC}$ ある。なお、 交流電圧では、モテル(a)を使用してPDIVのみを求めた。

\section{3. 試倹結果}

<3.1>ターン間絶綅モテルの結果図 5 に $\mathrm{S}$ 。ガス 压0.5MPa（以下すへて絶対圧）でのac, L. Impおよび、S. Imp のPDIVと絶縁被覆厚との関係を、また図 6 にL. ImpおよびS. ImpのBDVと絶縁被覆厚との関係を示す。さらに図 7 に急峻 波電圧のPDIV、BDV特性を示す。比較のため図 7 では + L. Im pの結果も示している。試験結果の縦軸は、絶縁被覆厚 $0.5 \mathrm{~m}$ mの + L. ImpのPDIV (37kV)を1.0と基準化して示してある。急 峻波電压のBDVはその発生装置の関係より絶縁被覆厚 $0.15 \mathrm{~mm}$ のみを求めている。

これらの結果より次のようなことがわかる。

電圧の種類によらず、PDIV、BDVは絶縁被覆厚にほぼ比例 し高くなる。また、PDIV、BDVとも印加電圧極性の違いによ る差は小さい。絶縁被覆厚 $0.5 \mathrm{~mm}$ の L. Imp試験結果で正、負 両極性による平均值の差の有意差検定を危険率5\%で実施し た結果、PDIV、BDVとも有意差無しの結果を得た。

急峻波電圧のPDIVおよびBDVをL.Impのそれと比較するとP DIVは上昇傾向が小さいものの、BDVは高くなっている。

<3.2>被要球ギャップモテルの結果图 8 にS F。ガ ス压0.5MPaでの部分放電開始電界 (PDIE) とパルス幅 (L. Imp では50 $\mu \mathrm{s}$ )の関係を示す。PDIEは被覆表面のガスギャップ 部の電界である。図からPDIEはパルス幅が短くなっても余 り上昇していないことがわかる。L.ImpのPDIEと比較すると、 35/65nsのそれは、1.1倍となっている。

部分放電が生じると、部分放電電流パルスの発生ととも に、ガスギャップ部で発光がみられた。しかし、その後PET 表面を観察したか、PETの貫通孔がみられないものがあり、 部分放電はS F。ガスギャップの破壊であることが推定され た。

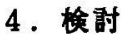

<4.1>ターン間モテルの部分放奄の発生場所につい 乙 L. Imp, S. Imp と屯部分放電開始時の部分放電は電压のほ ぽピーク部分で生じた。また、急峻波電圧では、電压のピ 一クのフラット部分で生じた。図 9 にI. Iを使用して観测し た35/65nsでの発光の様子を示す。部分放電が生じると電流 パルスの発生とともにターン間で形成されるくさび部分と 思われる部分で発光が認められた。この発光は急峻波電压、 L. Imp, S. Impでは電压を上昇させても必ずしも大きく広がら ず、むしろ 1 ステップ前で発光していた部分は次のステッ

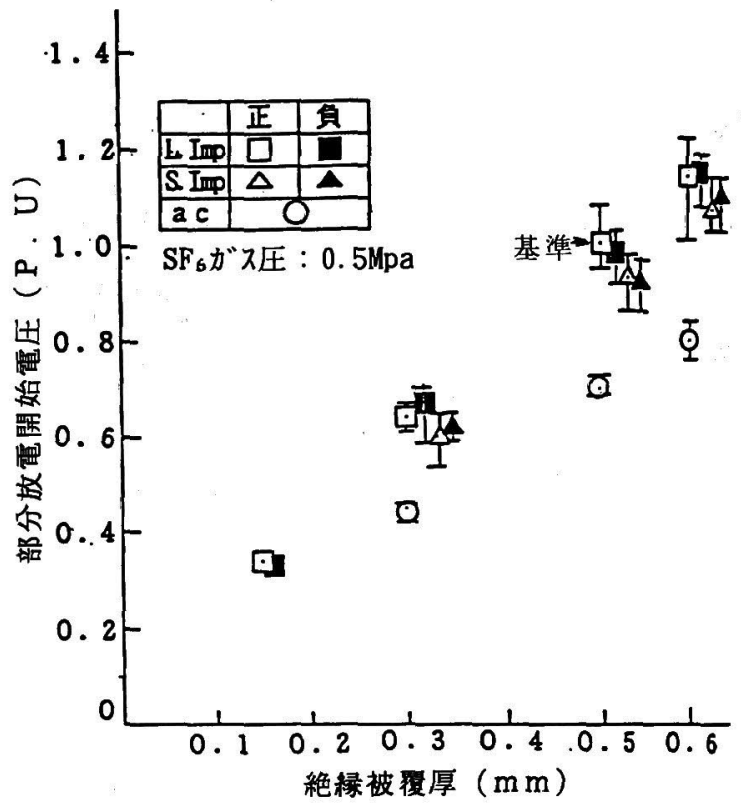

図 5 L Imp, S. Imp, acの 部分放電開始電圧

Fig. 5. Partial discharge inception voltages under L. Imp, S. Imp and ac

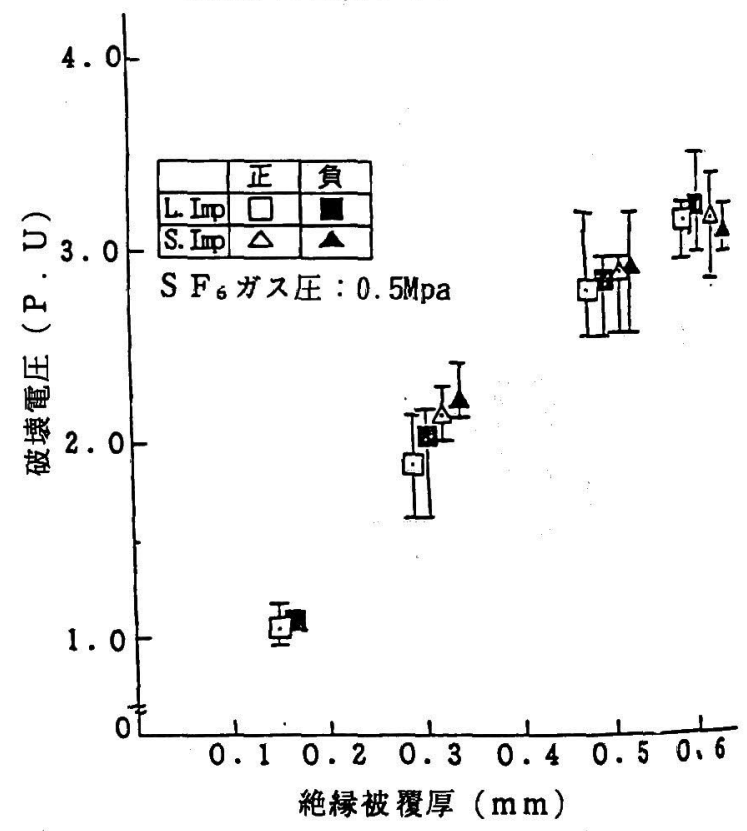

図6 L Imp, S. Impの破壊電圧

Fig. 6. Breakdown voltages under L. Imp and S. Im 


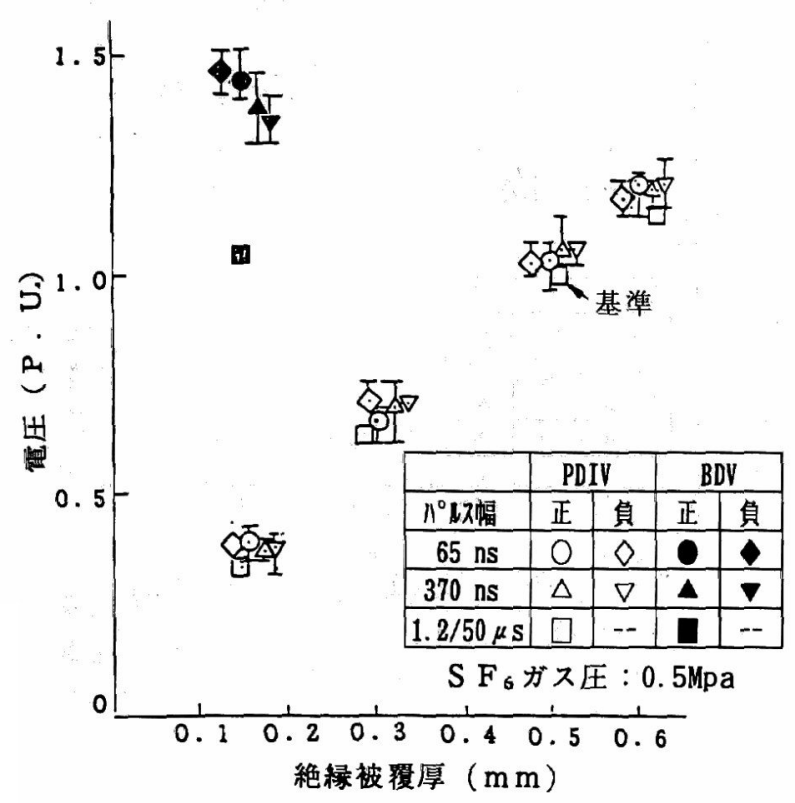

図7 急拨波電圧の試験結果

Fig. 7. Test results of steep front short duration pulse voltage

プでは発光が認められないことがあった。しかし、破壊前 の電圧で洁、ターン間全体で発光がみられた。これらの様 子は、印加電压の極性及び電压の種類によらずほぼ同じで あった。

L. Imp試験時の部分放電開始時の電流パルスを積分して部 分放電電荷を求めると500〜800pCであった。部分放電電荷 は電圧を上昇させても必ずしも大きくならず、小さくなる 場合もあり、PDIVの1.5倍程度までは500〜 3000pCであった。 部分放電に伴う発光が前述のような振る舞いを示すのは、 部分放電のストリーマによって、絶縁被覆表面に電荷蓄積 が生じ(10)、次のステップでの部分放電の発生を抑制する ためと考えられる。

一方、交流電压の場合は、部分放電開始時の部分放電電荷 は、50 70pCであり、電圧を上舁させるとL. Impの場合とは 異なり、部分放電電荷は急激に大きくなり、PDIVの 1.4 倍で は $1000 \mathrm{pC}$ 以上なった。これは、電正印加時間が 1 分間之 パルス電压と比較し長時間であることに加え、電压極性が 連続して反転しているためと考えられるい1。。お静止 写真で1分間開放によって撮影観测した結果、ターン間のく さび部分全体で発光が認められた。

部分故電発生後モテルをタンクより取り出し点検したか、、 絶縁物表面に放電痕は認められなかった。しかし、トナー によって帯電の有無を調查した結果、ターン間のくさびギ ヤップに相当する部分で帯電の発生が確かめられた。この 結果や部分放電に伴う発光場所から、インパルスで生じる 部分故電はくさび部分のガスの破壊によるものと考えられ る。

図10に50/370ns電仕での部分放電発生時の電流パルスの 例を示す。電流パルスは正、負両極性で生じている。これ は充電電流をキャンセルさせるため、2本の銅線から接地 電流が逆向きに流れるようにCTに接続している。従って部

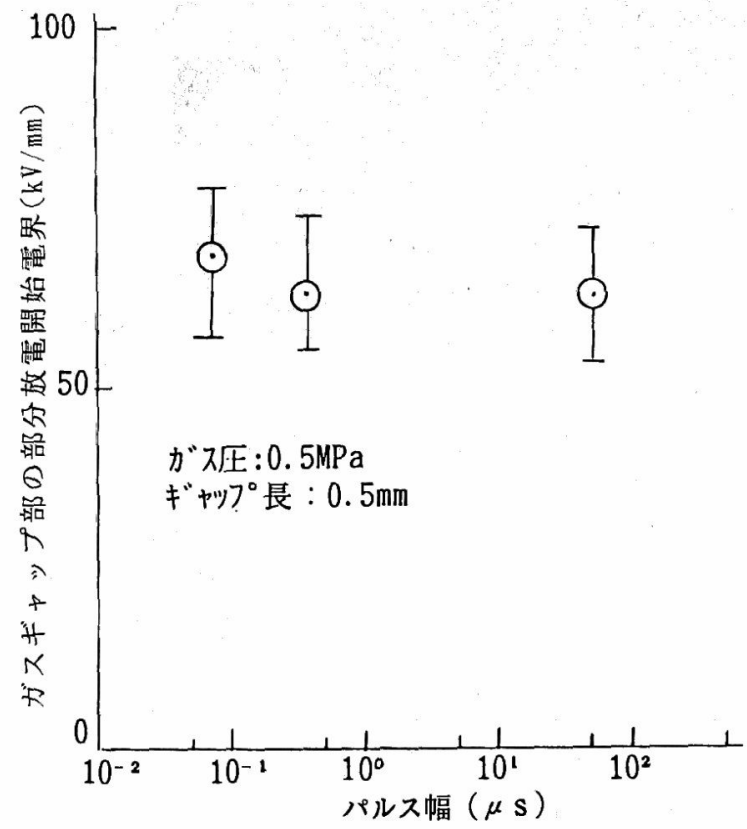

図8 被覆球ギャップモデルの試験結果

Fig. 8. Test results of spherical model

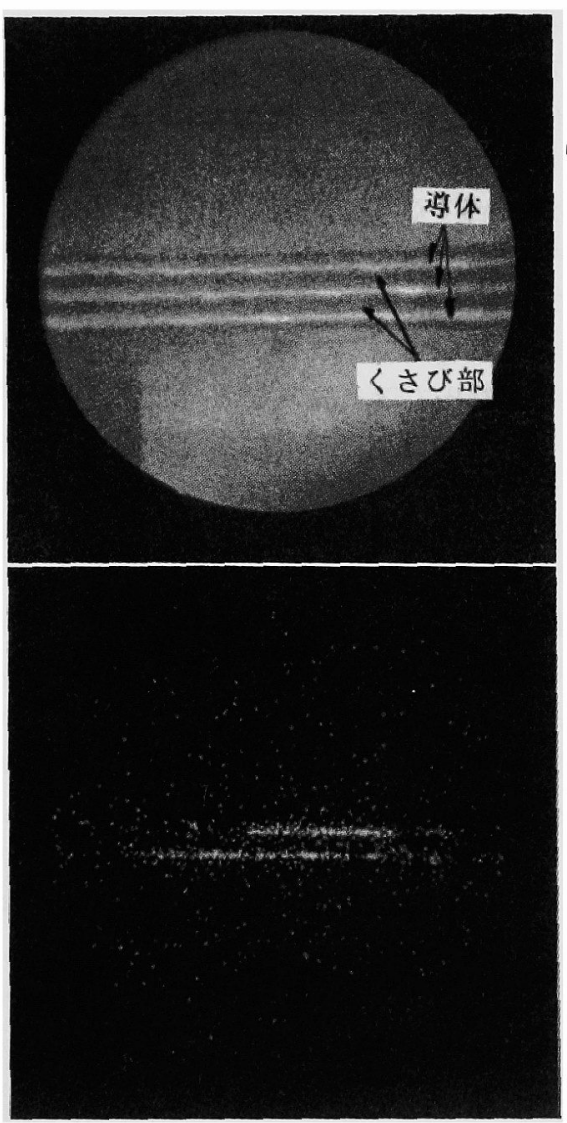

撮影範囲

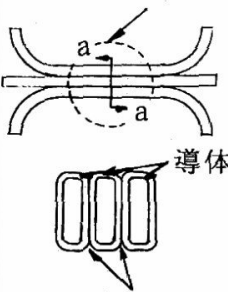

くさび部

$\mathrm{a}-\mathrm{a}$ 断面

導体の配置

くさび部の

発光状况
図9 部分放電発生による発光

Fig. 9. Light emission by impulse partial discharge 


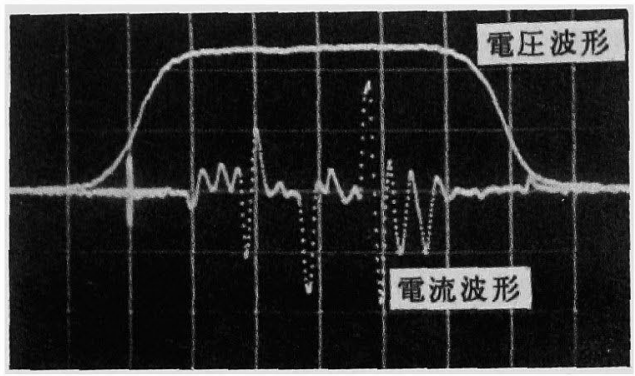

$62 \mathrm{~ns} / \mathrm{div}$

図 10 部分放電による電流パルス

Fig. 10. Current pulses by impulse partial discharge

分故電で 2 本の銅線に流れ込んだ電流は極性が反対になる。 つまり、正パルスは高周波CTの順方向に部分放電パルス電 流が流れるターン間で、また負パルスは逆方向のターン間 で部分放電が発生したことを意味している。

$<4.2>\mathrm{V}-\mathrm{t}$ 特性多ーン間モテルを使用して交流 電圧から急峻波電圧までの時間範团で求めたPDIVおよびBDV を $\mathrm{V}-\mathrm{t}$ 特性として図11、図12に示した。なお、縌軸はL. I mpでの正負それぞれの平均PDIVおよびBDVを 1.0 とし、横軸 はそれぞれの電圧のパルス幅あるいは半波尾長で示してあ る。

PDIVは波尾長が短くなってもその上昇傾向は小さく、た とえば、パルス幅65nsでは標準波インパルス電圧の1.05〜1. 15倍となっており、被覆球ギャップのPDIEとほぼ同じ特性 である。一方、BDVはS. Impのうち、tS. Impの絶縁厚0.3mmの 結果がL.Impと此較して高くなっているが、他の結果はL. Im pとS. Impではあまり差がない。なお、tS. Imp, 0.3mmの結果 のみがL. Impと比へて高くなった理由は不明である。そして、 BDVは急峻パルス電压で上昇し、パルス幅 $65 \mathrm{~ns}$ でL. Impの 1.3 〜1.4倍となっている。

部分放電の発生は、部分放電に伴う発光の観測からター ン間にできるくさび状のガスギャップの破壊であることが わかった。したがって、ターン間モデルのPDIVは被覆電極 微小ギャップでのガスの破壊特性に従うと考えられる。こ のようなことから、被覆電極を用いて、被覆微小ギャップ でのPDIEを測定したが、35/65nsの急峻波の場合でもL. Imp に対して1.1倍程度しか上昇しなかった。

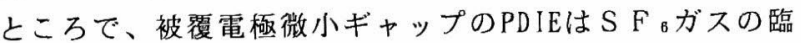
界破壊電界と比へ、約1.4倍となっている。被覆微小ガスギ ヤップの破壊電界は電極表面からの初期電子の発生が抑制 されるため裸電極でのBDVより高くなることが既に確かめら れており、このときの初期電子の供給源として、被覆表面 からの電子の電界故出が推定されている(12)。この考え方 によれば、被覆微小ギャップにおいては被覆表面の電界が ある値になれば、初期電子は十分供給されることになる。 さらに、準平等電界の微小ギャップでは、ストリーマの形 成時間遅れは極めて短いと考えられる。このようなことか ら、急峻波電压においてもPDIVの上昇傾向が小さくなった もの之考えられる。

これに対し、ターン間モテルが全路破壊にいたるために は、絶縁被覆を貫通する必要がある。破壊痕跡を観察する

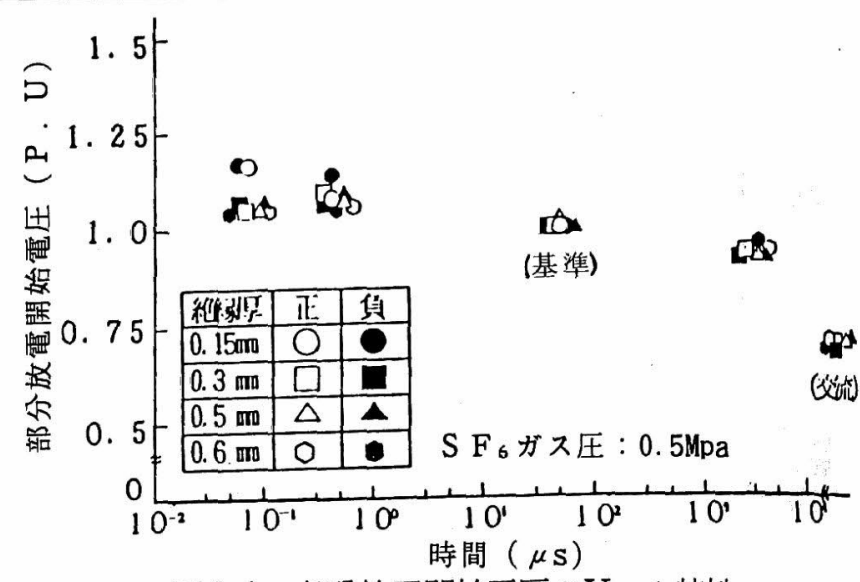

図 11 部分放電開始電圧の $V-t$ 特性

Fig. 11. V-t characteristics of partial discharge inception voltage

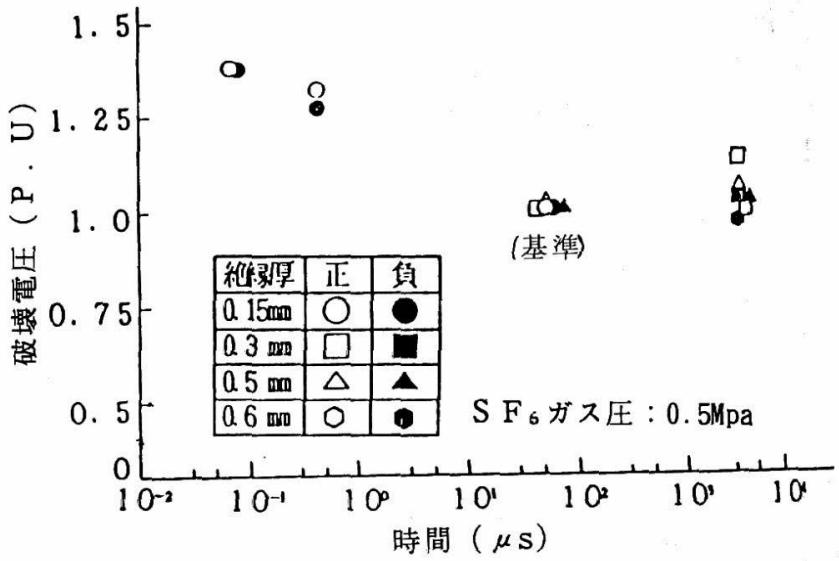

図 12 破壊電圧の $\mathrm{V}-\mathrm{t}$ 特性

Fig. 12. V-t characteristics of breakdown voltage と、被覆表面のフィルムが一部炭化し、溶けた跡があった。 すなわち、くさび部分のガスギャップで発生した部分放電 のエネルギーで絶縁フィルムが熱的損傷を受け破壊に至っ たと推定される。したがってBDVは、印加電压のエネルギー に左右され、印加時間の短い急峻波電圧のBDVがL.Impに比 ヘて高くなったものと考えられる。

<4. 3>インパルス比 表 1 にL. Imp及びS. Impに対す るPDIVと交流PDIVとの比（インパルス比）を示した。これ らより以下のことがわかる。

(1) L. Impに対するPDIVのインパルス比は 1.40〜1.48、S. Imp電圧に対するインパルス比は1.32〜1.37の範囲内にある。

(2)インパルス比は絶緑被覆厚さに依存しない。

これらのインパルス比は同軸円筒ギャップで求められた S F B ガスギャップのインパルス比 (13) とほぼ等しくなって いる。

表 1 PDIVのインパルス比 ( $\mathrm{S} \mathrm{F}_{6}$ ガス圧0.5MPa) Table 1. Impulse ratio of PDIV ( $\mathrm{SF}_{6}$ gas:0.5MPa)

\begin{tabular}{|l|c|c|c|c|}
\hline 電圧 & \multicolumn{2}{|c|}{ S. Imp } & \multicolumn{2}{c|}{ L. Imp } \\
\hline 被覆厚 & 正極性 & 負極性 & 正極性 & 負極性 \\
\hline $0.3 \mathrm{~m}$ & 1.33 & 1.37 & 1.41 & 1.48 \\
\hline $0.5 \mathrm{~m}$ & 1.34 & 1.32 & 1.43 & 1.40 \\
\hline $0.6 \mathrm{~mm}$ & 1.34 & 1.37 & 1.41 & 1.44 \\
\hline
\end{tabular}




\section{5.まとめ}

ガス絶縁変圧器ターン間絶縁モデルを使用して急峻波電 压を始めとして各種電压でのPDIVおよびBDVを求め次のよう なことが明らかになった。

(1) ターン間モテルのインパルス部分放電はターン間に 形成されるくさび部分で発光を伴って生じ、PDIVは絶縁被 覆厚にほぼ比例して高くなる。また、インパルスBDVも絶縁 被覆厚が厚くなるほど高くなる。

(2) ターン間モテルのインパルスPDIV、BDVに印加電压の 極性による相違は認められない。

(3) ターン間モテルのPDIVは波尾長が $1 \mu$ S以下になって も上昇傾向が小さい。一方、BDVは波尾長が短くなる上上昇 する。パルス幅 $65 \mathrm{~ns}$ の急峻波電圧の場合、標準波インパル ス電压と比へPDIVが1.05〜 1.15倍、BDVが1.4倍となった。 これは、PDIVはターン間にできるくさびギャップ部分のS

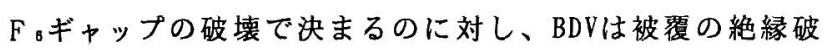
壊で決まるためと考えられる。このことは被覆微小ガスギ ヤップの試験結果からむ確かめられた。

(4) 雷インパルス電圧に対するインパルス比は1.40１.4 8、開閉インパルス電压に対するインパルス比は $1.32 \sim 1.37$ の範囲内にある。

なお、今回の破壊試験結果はステップアップ法の結果で あり、今後インパルス部分放電による残留電荷の影響につ いても検討する必要があると考えられる。

(平成 8 年 1 月 22 日受付、同年 5 月 15 日再受付)

(1)塩野、池田、川嶋：「ガス絶縁変压器の現状上動向」, 電学論 $B, 110-7,522$ (平2)

2)高橋、伏見、濱田、戸田、小林、池田、寺西、稲葉 :

$\lceil 275 \mathrm{kV}$ 300MVA ガス泠却式ガス絶縁変圧器の完成」, 平6

年 電力エネルギー部門大会 論文2 No.585 (平6)

3)小林、熊谷 : 「ガス絶縁変圧器巻線モテルのV-t, V-N特

性」電学論 B，10-7, 533(平2)

(4)Y.Yanabu,H.Murase,H.Aoyagi,H.Okubo,Y.Kawaguchi

'Estimation of Fast Transient Over-voltage in Gas-Insulated Substation",IEEE Transaction on Power Delivery Vol.5,No4 Nov.1990

5)S.Matsumoto,H.Aoyagi,H.Murase,Y.Ozawa,I.Ohshima:

Non-Uniform Field Flashover Characteristics in $\mathrm{SF}_{6}$ Gas Under 'ositive Steep-Front and Oscilating Impulse Voltages",IEEE 10IC581-9 PWRD Oct.1990

6)A.J.Vandermaar,M.G.Wang,J.B.Neilson,K.D.Srivastava "The 'haracteristics of Oil-Paper Insulation Under Fast Front Impulse loltages": 8th ISH,pp.239-242,1993

7)T.Teranishi,et al "A $600 \mathrm{kV}$ Blumlein Modulator for an X-Band Ilystron", 8th IEEE Pulsed Power Conference,pp.315-318 anDiego, June, 1991

B)村瀬、大久保、青㧕、柳父：「G I S 用 1 G Hz急しゅ 波サージセンサの開発」, 電学論 B, 109,1(平元) P)A.Inui,T.Inoue,T.Teranishi,H.Murase,I.Ohshima,K.Toda
"Dielectric Characteristics of Static Shield for Coil-End of Gas Insulated Transformer"; IEEE EI, Vol.27, pp.572-577, June (1992) (10)H.Muramoto,Y.Yamagata,A.Inui,T.Teranishi,I.Ohshima,T.Yanari "Partial Discharge Characteristics of Wedge Gap in SF6 Gas-Insulated Transformer" 7th ISH, 31.10 pp.45-48 1991

(11)乾、寺西、大久保、柳父「S F 。ガス中くさびギャップ における部分放電特性」，電学論 $A, 110,2$ (平2)

(12)花井、寺西、村瀬、大島「雷インパルス電圧に対する S F 6 ガス中被覆微小ギャップの絶縁特性」平3年 電力エネ ルギー部門大会 論文1 No.43 (平3)

(13)川口、毛受：「S F 6ガス絶縁の技術的諸問題」東芝レ ビュー、25-2(昭45)

井上保（正員）1949年7月3日生。1968年3月宮崎工業高

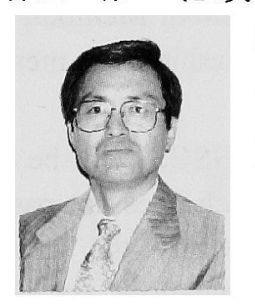
校電気科卒業。同年 4 月（株）東芝入社。 以来重電技術研究所において主として油 入変圧器及びガス絶縁変压器絶縁の研究 に従事。

寺西常治（正員）1946年2月10日生。73年3月名古屋大学

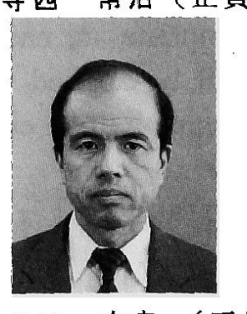
大学院電気工学専攻博士課程修了。同年4 月(株) 東芝入社。変仕器開発設計に従 事。79年より主として変圧器絶縁に関す る研究に従事。工学博士。IEEE会員。

谷口安彦（正員）1947年8月25日生。1968年3月有明工業

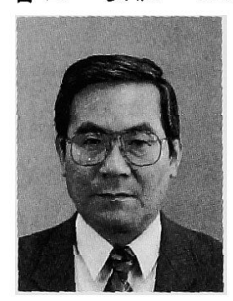
高等専門学校電気工学科卒業。同年 4 月 (株) 東芝入社。以来、重電技術研究所に おいて、がいし活損及び変圧器絶縁の研 究に従事。

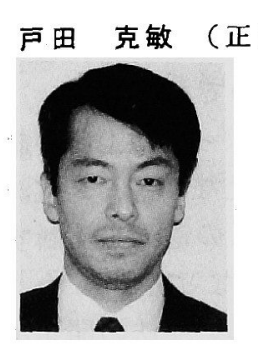

） 1956 年 12 月 1 日生。1981年東京大学大 学院電気工学修士課程修了。同年4月(株) 東芝入社。主として電力用変圧器、ガス 絶縁変圧器の開発に従事。

矢成敏行 (正員) 1938年8月1日生。1962年3月東京大学

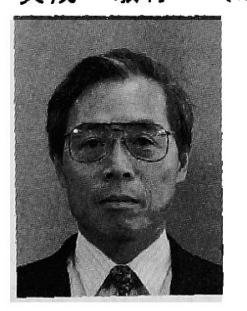
工学部電気工学科卒業。同年4月 (株) 東 芝入社。主として電力用変圧器の開発な らびに設計に従事。1984年電気学会論文 賞受賞。工学博士 